\title{
Grundtvig og Gammel Testamente - den danske Bibel eller Septuaginta?*
}

\author{
Af Christian Thodberg
}

Den gammeltestamentlige poesi er i tidens løb blevet tydet og gendigtet og er dermed blevet det medium, hvorigennem man bedst har kunnet studere den kristne poesis afgørende betydning for udfoldelsen af teologiske lærepunkter.

Her vil jeg - ikke overraskende - henlede. opmærksomheden på Grundtvig og et bestemt element $\mathrm{i}$ hans poesi. For ham indgik Gammel Testamente først og fremmest som et naturligt led i kirkens historie på vejen fra Skabelsen til Guds Riges fuldendelse. Han udtrykte det på denne måde:

»Det Gamle Testamente er det store Kirke-Speil fra Gulvet til Loftet, fra Jorden til Himlen, hvor de, hvis Aand Gud opvakde, hvis Øine Han oplod, hvis Tunge-Baand Han løste, det store Speil, hvori de alle skal betragte Kirke-Skibets Færd paa Verdens Hav mod Himlens Havn, og høit udraabe hvad de see og hvad de skimte til Oplivelse, Oplysning og Opmuntring for Herrens Folk, til at gøre Hans Gierning og prise hans Navn «. ${ }^{1}$

Med dette syn behøvede Grundtvig heller ikke i Gammel Testamente at tage Ny Testamente på forskud. Sagt anderledes: Grundtvig havde ikke nødig med vold og magt at tolke hvert ord i Gammel Testamente som handlende om Kristus. Det var den samme Gud, der handlede $\mathrm{i}$ begge dele af Bibelen, om end på forskellige måder alt efter den orden, hvormed Han førte og opholdt sit folk.

I kraft af sine salmer og sine bibelhistoriske sange har Grundtvig inspireret sine landsmænd til en mere fri og naturlig holdning til Gammel Testamente, end det har været tilfældet andre steder.

Det præger også Grundtvigs prædikener, der er bibelske på en sådan måde, at man - paradoksalt udtrykt - ikke mærker det! Han skubbede nemlig ikke Bibelen foran sig på den klæge argumenterende facon, som man møder hos de prædikanter, der med ophobningen af alt for tydelige skriftsteder vil bevise kristendommens bibelske troværdighed uden selv at komme i klemme. Grundtvig derimod bevægede sig frit og uanstrengt rundt $i$ hele det bibelske univers. Han kunne uden tvivl Chr. VI's 1736-Bibel udenad, og sommetider består 
halvdelen af hans prædikener af bibelske citater og allusioner - igen uden at man mærker det, fordi man helt og holdent overvældes af hans sproglige evne.

Den kommer til fuld udfoldelse, når han med få midler omdanner Ps. 96 til, hvad der svarer til et prosadigt i stil med Edda-digtningene, og hvor han tydeligvis bruger Davids-psalmen som afsæt til sine egne doxologiske udsagn i samme stil - først Ps. 96, vers 11-13, og dernæst Grundtvigs egen fortsættelse: ${ }^{2}$

Himlene glædes

og Jorden fryde sig,

Havet med dets Fylde bruse,

Marken fryde sig

Ps.96,12

med alt hvad der er paa,

alle Træer i Skoven synge med Fryd,

thi Herren er kommet,

Frelsen er aabenbaret,

Freden forkyndt,

Lyset oprundet,

Frygten viger,

Haabet stiger

høit over alle Stjerner

høit over alle Tider

med dens Omskiftelser,

til Stjernernes Skaber

i himmelske Huus,

til Tidernes Fylde

i Evigheds Land.

Den samme højstemte gammeltestamentlige stil kan dominere en prædiken fra den ene ende til den anden - især når en velforberedt prædiken har en bestemt indholdsmæssig struktur. Det gælder de prædikener, der kan sammenlignes med en trefløjet altertavle. På tavlens venstre side anføres den gammeltestamentlige profeti, på midtersiden afmales profetiens opfyldelse ved Jesu komme, og på tavlens højre side det vigtigste, nemlig profetiens opfyldelse i samtiden, hvor Grundtvig ikke undlader at sætte sin egen virksomhed i 
centrum, vel at mærke - naturligvis - som et led i frelseshistoriens forløb.

Denne særlige strukturering af prædikenen, der er særdeles virkningsfuld, kan også optræde $\mathrm{i}$ form af en salme, f.eks. den velbekendte Blomstre som en rosengård, som desværre kun kendes i den amputerede udgave i salmebogen. Her præsenteres den originale udgave, men for at illustrere, hvad vi har tabt i forhold til salmebogen, har jeg forsigtigt sat en tynd streg over de manglende strofer. Men først og fremmest gælder det originalens 15 strofer: 
Esajas' profeti

1.

Blomstre som en Rosen-

Gaard

Skal de øde Vange,

Blomstre i et Gylden-Aar

Under Fugle-Sange!

Mødes skal i Straale-Dands

Libanons og Karmels Glands, Sarons Yndigheder!

2.

Prises skal fra Strand til Strand

Jordans øde Slette,

Hæders-Krandse trindt om

Land

Skal til den man flette,

For med Guddoms-Herlighed

Der den Høie daled ned,

Lod sig klart tilsyne.

3.

Ryste meer ei noget Knæ!

Lad ei Hænder synke!

Skyde hvert udgaaet Træ!

Glatte sig hver Rynke!

Reise sig det faldne Mod!

Rinde let uroligt Blod!

Frygt og Sorg forsvinde!

4.

Herren kommer, Gud med os!

Troen paa Ham bier!

Byde vil Han Fienden Trods,

Som sit Folks Befrier,

Alt betales paa et Bret;

Fienden skeer sin fulde Ret,

Folket dobbelt Naade!

5.

Skiæres for den sorte Stær

Skal da Øine mange,

Døve Øren fjern og nær

Høre Fryde-Sange!

Som en Hind da springer

Halt,

Stammer, som for maalløs

Gjaldt,

Løfter klart sin Stemme!
6.

Saa i Herrens Helligdom

Esaias spaa'de,

Tiden randt og Dagen kom

Med Guds Lys og Naade,

Ja med Guds og Davids Son,

Som giør end i Lys og Lon

Paradis af Ørke!

7.

Vidtberømt da gjorde Han

Jordans øde Slette,

End til den vi trindt om Land

Hæders-Krandse flette:

Der vor Gud i Bad og Bøn,

Fandt sin elskelige Son,

Favned Ham i Aanden!

8.

Da tilgavns fik Blinde Syn, Stumme Røst og Mæle, Springe, fare kan som Lyn Nu vanføre Sjæle,

Hvad engang paa Støv blev seet,

Tusindfold i Aand er skeet, Skeer til Verdens Ende.

9.

Ja, vor Frelser og vor Drot, Jesus, den Eenbaarne,

Alting gjorde nyt og godt,

Selv hos Uomskaarne:

Aand Han blæser i vort Støv, Lydhør bliver da hver Døv, Stamihak en Taler!
Grundtvigs samtid

15.

Høit bebude Gylden-Aar

Glade Nyaars-Sange!

Blomstre som en Rosen-

Gaard

Skal de øde Vange!

Mødes skal i Straale-Dands

Libanons og Karmels Glands, Sarons Yndigheder!

14.

$\mathrm{Ja}$, det store *Hephata*

Atter kraftig lyder!

Daglig vort Halleluja

Stærkere udbryder!

Halte Been giør sikkre Trin!

Op sig lukker Sjal og Sind

For Guds-Mundens Aande!

13.

Ere med vor høie Drot!

Med Hans Aand tillige!

Sammen de giør Alting godt

I vort Himmerige,

Dove selv paa Gravsens

Bredd,

Øren faae at høre med,

Stummes Læber sjunge!

12.

Hurtig dog sig vendte Blad,

Slukket er nu Sorgen,

Det i hver en christen Stad

Aften blev og Morgen,

Medens vi, som tale end,

Troed, tvivled, traf igien

Herrens Aand i Støvet!

11.

Mode blev det, trindt paa

Jord,

Herren at fornægte,

Og af alle Jesu Ord

Eet kun syndes ægte,

Eet kun lagt i Sandheds

Mund,

Ordet: Om en liden Stund

Seer Man mig ei længer!

10.

Nys vel syndes Naadens Tid

Paa vor Jord udrundet,

Herrens Ord af Mandevid

Klarlig overvundet;

Trindt i Kirken, hvor Man 
I den venstre kolonne ser vi den berømte profeti fra Esajas, kap. 35, i strofe 1-5. Afsnittet i midterfeltet (strofe 6-9) refererer tydeligt til det foregående, når det (strofe 6) hedder: »Saa i Herrens Helligdom / Esaias spaa'de «, og når det fortæller, hvordan Jesus virkeliggjorde, hvad Esajas havde forudsagt. I det højre felt, hvor jeg lader stroferne 10-15 løbe nedefra opefter, skildres profetiens anden opfyldelse i samtiden.

Jeg lader disse strofer løbe nedefra opefter for at anskueliggøre, hvordan opfyldelsen af profetien så at sige fra bunden langsomt baner sig vej i retning af den endelige opfyldelse med strofe 15: »Høit bebude Gylden-Aar / Glade Nyaars-Sange!

Det er idéen om den såkaldte »V-struktur « $\mathrm{i}$ visse Grundtvigsalmer, der får mig til at lade stroferne i det højre felt gå nedefra opefter. Sædvanligvis betegner denne bevægelse trøsten i forhold til en foregående klage, f.eks. $i$ »Vor Herre! til dig maa jeg tye «. ${ }^{3}$ Her er situationen lidt anderledes. I denne salme fremtræder Esajas' profeti og Kristus som dens opfyldelse som så stærke vidnesbyrd om Guds indgriben i fortiden, at menigheden i Grundtvigs samtid kun langsomt erkender, at det også gælder dem.

Her møder vi altså trøsten i strofe 10-15, men med den gevinst, at det bliver tydeligt, hvordan strofe 15 svarer på stroferne 1 og 6, og hvordan man, hvis man fortsætter med at læse oversigten i vandret orden, kan se, hvordan stroferne 2, 7 og 14 svarer til hinanden, nemlig Esajas' bebudelse af dåben i Jordan (strofe 2), Jesu egen dåb i Jordan (strofe 7) og fornyelsen af dåben i den danske kirke i kraft af Grundtvigs »mageløse opdagelse « (strofe 14). Det store »Effata« er et billede på åbningen af øre og mund - den fulde retablering af gudbilledligheden, som dåben udvirker.

Det er således dåben, der er hovedtemaet her som i mange andre Grundtvig-salmer. Det tema er helt forsvundet i den version af salmen, som vi kender fra nr. 60 i salmebogen. Og det skal også nævnes, at det var Grundtvig selv, der senere udelod de omtalte strofer.

Det er kritisk mod Grundtvig blevet indvendt, at han var i stand til at finde dåben hvorsomhelst i Den hellige Skrift, og derfor har jeg også tidligere forestillet mig, at det er denne energiske påståelighed, der har fået Grundtvig til i strofe 2 at lade Esajas sige: 
Prises skal fra Strand til Strand

Jordans $\varnothing$ de Slette,

for i Esajas kap. 35, vers 2a, nævnes Jordan slet ikke. I 1736-Bibelen hedder det om ørkenen: »Den skal vist blomstres, ja den skal fryde sig, og synge med fryd «. Den kendsgerning har længe generet mig, nemlig at Grundtvig i sin dogmatiske interesse skulle have forfalsket Bibelen - lige indtil jeg $\mathrm{i}$ stor rådvildhed $\mathrm{i}$ mangel af bedre slog op $\mathrm{i}$ Septuaginta på det samme sted. Dér står: »Og blomstres og glædes skal Jordans $\emptyset$ de steder «!

Der kan således ikke herske tvivl om, at Grundtvig bevidst har taget sin tilflugt til Septuaginta og netop dér fundet det Jordan-motiv, der er afgørende for salmens idé. Det havde han så meget lettere ved, fordi hans græsk-kundskaber var så omfattende, at Septuagintas lidt besværlige græsk ikke voldte ham vanskeligheder.

I modsætning hertil var hans hebraisk-kundskaber ikke store. Han fik karakteren »haud illaudabilis « ved optagelsen på universitetet $\mathrm{i}$ 1800, og han kommentererer selv sin karakter: "...Jeg troer, haud kunde gerne være borte. Frederik var en Stymper i Jødelæsning,... ${ }^{4}{ }^{4}$

I Verdenskrøniken 1814 siger han ligeud: »...at jeg er et Barn i de hellige Sprog, og kan ikkun stave saa smaat udi Faders Bog,..5, hvilket dog ikke afholdt ham fra i samme skrift at udbrede sig i enkeltheder om det hebraiske sprog som det mest poetiske, der fandtes. Hans sproglige analyse kan vistnok snarere karakteriseres som en paradeforestilling, der skal tjene til at legitimere hans egen »bibelske stil«, som vi allerede har stiftet bekendtskab med i de højstemte passager, hvor han starter med prosadigt-agtige bibelske citater for derefter selv at fortsætte med sine egne udsagn i samme stil. $^{6}$

Men tilbage til Septuaginta. Brugte han kun den græske bibel, fordi ordvalget på visse punkter passede ham bedre end Chr. VI's Bibels? Han synes i hvert fald også at have ideologiske grunde. Det fremgår bl. a. af den kendsgerning, at det først er i løbet af 1830'rne, at Septuaginta-teksterne spiller en rolle. Det hænger efter alt at dømme sammen med hans Irenæus-læsning, hvor Grundtvig gang på gang slår til lyd for, at den danske Bibel burde have taget mere hensyn til Septuaginta; han siger: »...jeg skjønner i det Hele ikke rettere, end at vore Oversættere af det Gamle Testamente havde gjort vel i, flittig at raadføre sig med de Halvfjerds, som unægtelig havde 
langt aldre Codices, end vi, og kunde udentvivl ogsaa lidt bedre Ebraisk «. ${ }^{7}$

Den allersidste bemærkning vidner om omhyggelige overvejelser og indirekte kritik af den 1736-Bibel, som hidtil havde været uantastelig for ham. Tillige virker han ejendommeligt moderne, fordi det netop er problemer af denne art, der i den aktuelle forskning har givet Septuaginta en større autoritet end før, fordi man i forbindelse med Qumran-fundene er stødt på hebraiske håndskrifter, der står Septuagintas tekst nærmere end vores almindeligt kendte Biblia Hebraica. ${ }^{8}$

At det ikke er tilfældig brug af Septuaginta, der her er tale om, fremgår af Grundtvigs prædiken på 3. søndag i advent 1841, hvor størstedelen af Esajas 35 lægges Jesus i munden som hans svar til den tvivlende Johannes Døber i fængslet (jf. dagens evangelium, Matt. 11,2-10). ${ }^{9}$ I oversigtens tre kolonner ser man prædiken-teksten fra 1841 i midten, Esajas-teksten i 1736-Bibelen til venstre og den samme Esajas-tekst fra Septuaginta i dansk oversættelse til højre: 
1. Men ørken og de tørre steder skal glæde sig derved; og den øde mark skal fryde sig, og blomstres, som en rose.

2. Det skal vist blomstres, ja den skal jo fryde sig, og synge med fryd, Libanons herlighed er givet den, Carmels og Sarons prydelse; de skal see HERRENS herlighed, vor Guds prydelse.

3. Styrker de afmægtige hænder, og bekræfter de snublende knæe.

4. Siger til de mistrøstige af hiertet: værer frimodige, frygter ikke; see, eders Gud skal komme med hæun, ja Guds betalning, han, han skal komme og frelse eder.

5. Da skal de blinde øine aabnes, og de døves øren aabnes.

6. Da skal en halt springe, som en hiort, og den stummes tunge synge med fryd, thi vandene ere adskilte $i \emptyset r k e n$, og bækkene paa den øde mark.

7. Og en tør sted skal blive til en søe; og en tørstig sted til vand-kilder; i den boelig, deri drager laae, skal være høe, tilmed rør og siv.

8. Og der skal være en banet vei, ja en vei, ingen ureen skal gaae derpaa, men den skal være for dem; den som vandrer paa denne vei, endog daaren, skal ikke fare vild.

9. Der skal ingen løve være, og intet rivende dyr kommer der op paa, eller findes der; men de igienløste skal vandre der.

10. Og HERRENS forløste skal komme tilbage, og komme til Zion med frydesang, og evig glæde skal være over deres hoved; fryd og glæde skal de bekomme, og sorrig og suk skal flye fra dem.

\section{3.s. i advent 1841}

glæd dig, du tørre Ørk! [thi] Ørken skal fryde sig og blomstre som Rosen

ja Jordans $\varnothing$ de Mark skal blomstre og fryde sig, Libanons Herlighed og Karmels Prydelse er givet den, og mit Folk skal see Herrens Herlighed og Guds Majestæt,

bliver stærke og frygter ikke, thi see, vor Gud vil skaffe Ret og giengialde. Han vil komme og frelse os!

Da skal de Blindes Øine aabnes og de Døves Øren høre

og De Stammendes Tunge bliver flydende, thi der er [udd] udbrudt et Vandspring i Ørken og en Kilde til at vande det Tørre, til Fuglenes Fryd,

Og der skal være en AdelsVei, den skal kalde Helligdoms-Vei og ingen Ureen skal betræde den

og der skal ingen Løve og intet [vildt] glubende Dyr findes, men Gienløste [skal bevandre] Herrens Forsamlede skal bevandre den, og de skal vende tilbage og komme til Zion med Fryd, den evige Glæde skal [være] svæve over deres Hoved med Lovsang, men Smerte, Suk og Sorg skal flye.
Esajas 35 i Septuaginta

1. Glaed dig, du tørstende фrken, jubler, du ørken, og blomstrer som en lilje.

2. Og blomstres og glædes skal Jordans $\phi d e$ steder, Libanons herlighed blev givet den, og Karmels ære, og mit folk skal skue Herrens herlighed og Guds højhed.

3. bliv stærke, I slappe hænder og i lammede knæ.

4. Trøster hinanden, I sørgmodige i sindet, bliv starke, frygt ikke.

Se, vor Gud skaffer ret, og han vil gengalde. Selv vil han komme og frelse os.

5. Da skal de blindes $\varnothing j n e$ åbnes, og de døves $\emptyset$ rer skal $h \phi$ re.

6. Da skal den lamme springe som en hjort,

og de stummes tunge skal blive tydelig, thi vand er brudt frem i ørkenen og en sprække af vand i tørstende jord.

7. Og det tørre land skal blive til enge, og til den tørstende skal komme en kilde af vand. Dér skal blive en fryd af fugle, boliger af rør og enge.

8. Dér skal være en ren vej, og en hellig vej skal den kaldes, og dér skal ingen uren gå endsige være en uren vej, men på den skal de forløste gå, og de skal ikke gå vild.

9. Og ingen løve skal være dér, ej heller et vildt dyr skal gå op på den, nej slet ikke findes,

10. og de for Herrens skyld forsamlede skal gå på den, og de skal vende tilbage og komme til Sion med fryd og med evig fryd over deres hoved. Thi over deres hoved skal være lovprisning og glæde, og fryd skal gribe dem, og borte er smerte, sorg og sukke. 
Citatet i Grundtvigs prædiken er som sagt kun et uddrag af Esajas kap. 35. Gengivelsen er undertiden ret fri, men der er ikke tvivl om Grundtvigs forkærlighed for Septuaginta-teksten på bekostning af 1736-Bibelen (i Septuaginta-kolonnen er de vigtigste ord, som Grundtvig henter derfra, anført med kursiv). At han har arbejdet direkte med den græske tekst, fremgår også af hans overstregede fors $\emptyset \mathrm{g}$ (i kantede parenteser).

Men tilbage til Blomstre som en rosengård. Netop når vi har set den sidste tekst, falder der lys over de kendte linier i den første strofe:

\section{Blomstre i et Gylden-Aar}

Under Fugle-Sange!

for enhver, der er fortrolig med Grundtvigs poetiske sprog og ordvalg, vil vide, at »fugle-sange « let faldt ham i pennen, fordi fuglen er en af de hyppigst forekommende figurer i Grundtvigs poesi, men faktisk henter han ordet fra Esajas-tekstens vers 7 i Septuaginta-versionen: »Dér skal blive en fryd af fugle «. ${ }^{10}$

Når Jordan hentes ind i Blomstre som en rosengård fra Esajas 35, vers 2, i Septuaginta, rejser det et fortolknings-spørgsmål. For når Jordan nævnes i salmens strofe 2, hentydes der til en begivenhed:

For med Guddoms-Herlighed

Der den Høie daled ned,

Lod sig klart tilsyne.

Der refereres altså til, at der i fortiden er indtruffet en begivenhed, som profeten bebuder en gentagelse af. Der er mange muligheder. Men det er rimeligt at følge den liturgiske tradition, der er nærmest til at pege på, hvad der hentydes til, nemlig til beretningen om profeten Elisa, der arvede den himmelfarne Elias' kappe, men som først erfarede kappens kraft, da han under påkaldelse af Herren, Elias' Gud, slog vandet i Jordan med kappen, så vandene veg til side og lod ham gå tørskoet over (2. Kongebog, kap. 2, vers 13-14). ${ }^{11}$

Om denne beretning handler netop en hymne fra aftenen før theofanidagen, den 6. januar, der endnu i den græsk-ortodoxe kirke har Jesu dåb (Matt. 3,13-17) som evangelietekst og overordnet tema - en reminiscens af, at dagen i gammel tid var dåbsdag. Esajas kap. $35 \mathrm{i}$ 
Septuaginta, der er den ortodoxe kirkes Gamle Testamente, hører til de faste læsninger, og hymnen lyder således:

\author{
Floden Jordan \\ veg fordum tilbage \\ for Elisas kappe, \\ da Elias var opfaren, \\ og vandene delte sig \\ til den ene og den anden side, \\ og det våde blev ham en tør vej \\ som et billede på den dåb, \\ hvormed vi går over livets \\ strømmende gangbro. \\ Kristus kom til syne i Jordan \\ for at hellige vandene.
}

Ved at udlægge Esajas kap. 35 knytter Grundtvig med andre ord uden at vide det en forbindelse til den oldkirkelige tradition. Men først og sidst: det er ikke for meget sagt, at Septuagintas gengivelse af Esajas kap. 35, vers 2, om Jordan er kernen og den teologiske pointe $\mathrm{i}$ originalversionen af Blomstre som en Rosen-Gaard. Nr. 60 i Salmebogen er kun en torso!

Eksemplet fra 3. søndag i advent 1842 er vigtigt; det viser, at Grundtvig ikke blot gør tilfældigt brug af Septuaginta, når han er på jagt efter en sproglig version, som han i særlige sammenhænge har brug for. Det drejer sig om en bred udnyttelse af den græske Bibel.

Irenæus-påvirkningen gør sig også gældende i den følgende tid, når det gælder opstandelsen og det evige liv, der kommer stærkere til orde i Septuaginta-versionen af Gammel Testamente. I en prædiken i 1836 over den rige mand og Lazarus citerer Grundtvig, hvad han kalder »Opstandelses-Psalmen«, nemlig Ps. 66, der kun i Septuaginta har den overskrift, og anfører fra psalmen vers 9-12 oversat fra Septuaginta, bl.a. vers 9: »Han bragde min Sjæl til Live og lod ikke mine Fødder vakle ${ }^{12}$

Grundtvig afsøger Gammel Testamente for ethvert vidnesbyrd om opstandelsen og finder det især i Septuaginta. Den skriftkloge Nikodemus kendte ikke Skriften godt nok, når f.eks. den fromme Job dog dybest set håbede på muligheden af en genfødelse - temaet $\mathrm{i}$ 
Nikodemus-samtalen. Grundtvig citerer Job (kap. 14, vers 14-15) i en ganske vist lidt ordrig gengivelse af Septuaginta-versionen:

»Ja, derfor siger Job i sin Fortvivlelse: godt og vel med Fængselet i Skyggernes Land og med Dvalen, naar din Vrede kun lagde sig, og du havde berammet en Tid, da du vilde komme mig ihu, thi naar døde Mennesker efter Levnetsløbets Ende havde Liv ivente, da vilde jeg bie paa Gienfødelsen og naar Du kaldte, skulde jeg høre, og Du tilintetgjorde da ikke dine Hænders Gierninger ${ }^{13}$

Men Septuaginta-indflydelsen mærkes også på andre og mere kendte steder. Da der i realiteten kun er mindre forskelle på 1736-Bibelens og Septuagintas tekster, drejer det sig i hovedsagen kun om små, men dog vigtige nuancer.

Man kan nævne en kendt strofe: ${ }^{14}$

Dine Fiender gaae tilgrunde, Ja, som Avner skal de Onde

Hvirvles, veires hen,

Mens i Alderdommens Dage

Herlig Kræfterne tiltage

Hos din gode Ven!

hvor de tre første linier er en ret tro oversættelse af Ps. 92, vers $10 \mathrm{i}$ den almindelige danske bibel. Anderledes er det med de tre sidste linier, der knytter sig til vers 11 . Her siger 1736-Bibelen i vers $11 \mathrm{~b}$ : »jeg overgyder dig med fersk olie«, mens Septuaginta i stedet for den sidste sætning lyder: »og min alderdom [skal være] i fed olie ${ }^{15}$

I grunden burde Septuaginta-afhængigheden ikke være så ukendt, som tilfældet er. For den bibelhistoriske sang »Mellem Brødre kaldt den Lille« har som overskrift »Davids Seiers-Sang (Efter den 151de Dav. Ps. $) \ll,{ }^{16}$ dvs. den overskydende Davidspsalme, der kun findes i Septuaginta.

Den bedste illustration af Septuagintas betydning for Grundtvig findes i hans oversættelse og gendigtning af Ps. 84: Hyggelig, rolig / Gud! er din Bolig, en af de Grundtvig-salmer, der i kraft af sit billedsprog hæver sig over andre. Salmen er formentlig blevet til i efteråret 1836 og trykt kort tid efter ${ }^{17}$ og senere med mindre ændringer optaget i Sangværkets 2. hefte (nr. 61): 
1736-Bibelen Ps. 84

2. Hvor elskelige er dine boeliger, HERRE

Zebaoth!

3. Min siel begierer og længes ogsaa at komme til HERRENS forgaarde; mit hierte og mit kiød raaber med fryd efter den levende Gud.

4. Ogsaa en spurre finder et huus,

og en svale en rede for sig, hvor den kan legge sine unger;

hos dine altere, HERRE Zebaoth!

min konge og mon Gud!

5. Salige ere de, som boe $i$ dit huus;

de skal endnu love dig, Sela!

6. Saligt er det menneske, hvis styrke er i dig; i hvis hierte de rette veye ere.

7. Naar de gaae igiennem morbærdalen, sette de ham for sig til en kilde;

$\mathrm{Ja}$, og en regn med velsignelser skal bedakke dem.
GSVI 61

1. Hyggelig, rolig

Gud! er din Bolig,

Inderlig skiøn!

O, hvor mit Hjerte

Længes med Smerte,

Sukker i Lon,

Efter at gæste din Helligdom

prud,

Efter at bo hos den levende

Gud!

2. Godhedens Kilde!

Aarle og silde

Giæstmild er Du!

Ved dine Sale

Spurv moder Svale,

Kom det ihu!

Som ved dit Alter den kvidrende Fugl,

Und i dit Tempel din Tjener et Skjul!

\section{Hos dig at bygge}

Høieste Lykke

Kaldes med Ret,

Der lyster Tunge

Altid at sjunge,

Vorder ei træt,

Til ikke lægger og tager ei fra Glædens det evige Halleluja!

\section{Alt dog hernede}

Lykkelig hede

Skal hvo dig tro'r;

I Himmerige

Tor han indkige

Frit paa dit Ord,

Ja, i hans Hjerte fra Taarernes Dal

Trappe Du bygger til Himmerigs Sal!
Septuaginta Ps. 83

2. Hvor attråværdige er dine boliger, o magternes Herre!

3. Min sjæl laenges og däner efter Herrens sale, mit hjerte og mit kød har jublet for den levende Gud.
4. Thi dér fandt spurven sig et hjem og duen sig en rede, hvor den kan lægge sine unger, dine altre, magternes

Herre, min konge og min Gud!

5. Salige er de, som bor i dit hus,

til evig tid skal de love dig. Diapsalmata.

6. Salig den mand, hvis hjælp er hos dig, o Herre.

Trapper $i$ hans hjerte satte han

7. i gràdens dal, til det sted, som han satte. Thi dér vil lovgiveren give dig velsignelse.
8. De skal gaae fra kraft til kraft; hver af dem skal sees hos Gud i Zion.

9. HERRE Gud Zebaoth! hør min ben, Jakobs Gud! vend dit øre dertil, Sela!

10. Gud! vor skjold, see, og skue din Salvedes ansigt.
8. De skal gå fra styrke til styrke.

\section{Lykkes og trives,} Styrkes, oplives, Skal dine Smaa, Voxe i Kræfter, Stige derefter, Høieloft naae,

Himle, hvor Øiet, som grader ei meer,

Gudernes Gud i sin Herlig- Gudernes Gud skal ses pá 
11. Thi en dag er bedre $i$ dine forgaarde end ellers tusinde;

jeg udvælger hellere at være hos dørtærskelen i min Guds huus, end at boe i de ugudeliges pauluner.

12. Thi den HERRE Gud er soel og skjold; HERREN skal give naade og ære, han skal intet godt vegre dem, som vandrer i fuldkommenhed. 13. HERRE Zebaoth! saligt er det menneske, som forlader sig paa dig.
6. Tusinde Døgne, Verdslige, søgne, Gyldne for Kiød, Kan de vel ligne Een Dag af dine, Som vi dem nød,

Naar under Sang, med dit vingede Ord,

Sjælen afby over Stjernerne foer!

7. Ei vil jeg bytte, Gud, i din Hytte, Betlerens Plads Bort for det Sæde Stolte beklæde

Høit i Palads!

Godt ikke fattes, hvem Gud haver kiær!

Lavt er ei bænket, hvem du sidder nær!

\section{Sandhed og Naade,} Det er din Gaade, Stor-Herre bold!

Salig at prise

Er den Retvise, Du er hans Skjold, Øie du holder med salvede Smaa, til for dit Ansigt de kronede staae!
9. Herre, magternes Gud, hør dog, bønhør, du Jakobs Gud.

10. Du er vor forsvarer, se, og se din salvedes àsyn.

11. For bedre én dag i dine sale end tusinder.

Jeg valgte at være $i$ en krog $i$ Guds hus end at bo i syndernes boliger.

12. For barmhjertighed og sandhed elskede Herren, vor Gud. Herren vil ikke forholde dem sine goder, der vandrer i uskyld.

13. $O$, du magternes Herre, saligt det menneske, der hàber på dig. 
For at anskueliggøre Grundtvigs forlæg anføres i oversigten i midterste kolonne salmen i versionen fra Sangværket, til venstre Davidspsalmen i 1736-Bibelen og til højre psalmen i Septuaginta (Ps. 83). I det sidste tilfælde atter i ordret dansk oversættelse. Det sker her som i de foregående eksempler for overskuelighedens skyld; Septuagintas græsk er ikke helt ligetil. I Septuaginta-kolonnen er de vigtigste ord, som Grundtvig refererer til, atter skrevet med kursiv.

I vore øren lyder det første ord »hyggelig « om Guds bolig forkert, men ordet havde vistnok på Grundtvigs tid en lidt anden betydning, nemlig »omgærdet med omhu «. ${ }^{18}$ Måske har Grundtvig selv været $\mathrm{i}$ tvivl om ordvalget, når det $\mathrm{i}$ et af de første udkast hedder "Munter og rolig «. ${ }^{19}$ Mange ville sikkert $\emptyset$ nske, at man turde foreslå, at salmens første linie begyndte sådan!

I det flg. skal især fremhæves de træk, der viser, hvilket forlæg salmen er afhængig af. Med kursiv er anført de ord og vendinger i henholdsvis 1736-Bibelen og Septuaginta, som salmen refererer til. Selv om det kan synes overflødigt, skal det dog siges, at den poetiske udtryksmåde i den rimede salme naturligvis må forholde sig ret frit til sit forlæg. Hvad man kan konstatere, er ifølge sagens natur kun nuancer.

Når det i strofe 1 hedder, at sjælen længes med smerte efter Guds bolig, synes dette stærke udtryk især at komme fra Septuaginta-versionen og ordene: »Min sjæl længes og dåner efter Herrens sale «. ${ }^{20}$

Når der i denne strofe og i salmen overhovedet tales om Guds bolig, er det i Gammel Testamente tydeligvis templet i Jerusalem, der tænkes på. For Grundtvig er Guds bolig her og andre steder noget andet end en kirkebygning eller den jordiske kirke overhovedet. Den menighed, der samles til gudstjeneste er »kun et gæstekammer / til en himmelsk altergang « (DS 306,6). Guds bolig - den egentlige kirke åbenbares først ved tidernes ende, når Kristus kommer igen og henter sine børn hjem. Hele denne salme kommer således til at handle om spændingen imellem og vejen imellem »gæstekammeret « og den evige himmelske bolig.

I Strofe 2 prises Gud som "godhedens kilde« - måske en reminiscens af Ps. 42's ord om mennesket, der længes efter Gud som hjorten efter det rindende vand (jf. DS 377). Ellers er strofen en trofast gengivelse af Ps. 84 vel at mærke i 1736-Bibelen med omtalen af spurven og svalen. I den sammenhæng forkastes spurven og duen $\mathrm{i}$ Septuaginta, for de danske sangfugle var forlængst for Grundtvig 
blevet, hvad han kalder »Gudshusets tamme Fugle ${ }^{21}{ }^{21}$ Bønnen om, at mennesket i Guds bolig må få samme ret som spurven og svalen, opfyldes i det $\emptyset$ jeblik, menneskets lovsang bryder ud lige så spontant som fuglenes og englenes lovsang og smelter sammen med deres (jf. DS 10). Dermed er vejen banet for den næste strofe.

I gendigtningen af kirkelig poesi begejstres Grundtvig i særlig grad, når han hos andre møder ord og vendinger, der kan forstærke hans egne teologiske mærkesager. Det gælder i forbindelse med strofe 3 ordene i Ps. 84, vers 5 i Septuaginta: »til evig tid skal de love dig «, der minder om gudbilledlighedens fornemste udtryk: den lovsang, der er menneskets bestandige svar på Guds tiltale (DS $335,1)$ :

Lyksaligt det folk, som har øre for klang

herovenfra!

Det nynner alt her på den evige sang:

Halleluja!

Mest spændende er afgjort strofe 4: allerede i det jordiske liv skal den troende prise sig lykkelig, fordi gudstjenesten i et glimt lader fuldendelsen komme til syne. Selv det mest anfægtede og sørgende menneske får en forsmag på Guds rige, når han eller hun i sit hjerte på lovsangens tonestige nærmer sig himlen på fugles og engles vis! Hermed har jeg allerede tolket, hvordan Grundtvig udlægger vers $6 \mathrm{~b}$ - 7a i Septuaginta: »Trappe i hans hjerte satte han, i grådens dal, til det sted, som han satte «. ${ }^{22}$

Jakobsstigen (1. Moseb. 28,12) havde Grundtvig tidligere tolket som billede på den forbindelse, som lovsangen knytter mellem himmel og jord (DS 81,7):

Da vandre Guds engle op og ned

på salmens tonestige,

men her - i Septuaginta - får han så at sige bekræftet sin tolkning! Jeg vil vove den påstand, at det er denne græske tekst, der har været drivkraften til hans gendigtning af denne Davids-psalme. Her møder han på græsk de ord, der for ham udtrykker lovsangens dybeste mening: at den baner sig veje fra gråden til glæden. ${ }^{23}$ 
Tankegangen fortsættes hos Grundtvig i strofe 5, hvor vers 8 i de to forlæg udlægges som udtryk for hans kendte tanker om kristenmennesket på frelsens vej, indtil det »himler « og når frem til Guds bolig i fuldendelsen, hvor det skal se Gud ansigt til ansigt. Det er ikke de salige, der skal ses af Gud (1736-Bibelen), men det er Gud, der skal ses af de salige (Septuaginta).

I strofe 6 vender Grundtvig tilbage til søndagen, der udmærker sig frem for de søgne dage - en hovedsag for ham i Sangværket. Det er på denne dag, lovsangens tonestige når op over alle stjerner. Det skyldes naturligvis lovsangens hemmelige kraft, som den får fra den modgående bevægelse fra himmel til jord, nemlig fra Guds-ordets tiltale, der udløser den bøn og den lovsang, der går fra jord til himmel.

Om denne opstigende bevægelse i strofens to sidste linier siger en moderne »intertekstuel tolkning«: »det sker under poesiens betingelse, nemlig med Guds »vingede Ord« $(6,7)$ og »under Sang (sst.) «.$^{24}$ Men det er ikke poesien, der kvalificerer Guds »vingede Ord« som just Guds ord. Dermed ville man tillægge Grundtvig en eksklusiv romantisk poesi-opfattelse, der samtidig ville lukke den teologiske pointe ud af Grundtvigs salmer. Sagt anderledes: teologerne har stadigvæk noget at skulle have sagt til litteraturvidenskaben!

Og ganske kort om resten af salmen: I strofe 7 gengives Davidspsalmen vers 11b: at være i Guds nærhed overgår den højest tænkelige jordiske status.

Strofe 8 er udeladt i salmebogen, der således mangler salmens egentlige slutning og konklusion. Fra Septuaginta henter Grundtvig ordene »barmhjertighed og sandhed «, som han gengiver med det mere kendte ordpar "Sandhed og Naade", som han ligesom andre steder tolker johannæisk (Johs. 1,17): Gud er sandhed, dvs. den uantastelige almagt og indiskutable verdensforklaring, men samtidig er Han nåden i sin utrættelige omsorg for sin skabnings opholdelse og endelige frelse. At det er sådan, er for en menneskelig betragtning gåden.

Ordet »Skjold « henter Grundtvig fra 1736-Bibelen: Gud er den retsindiges værn og skjold, men først og fremmest gælder Guds omsorg hans »salvede Smaa«, indtil de ser Ham ansigt til ansigt.

De salvede er de døbte, og når ordet »salvede Smaa« overhovedet kommer ind, er det formentlig en dristig omtolkning af Davidspsalmens vers 10 om Gud, der ser sin salvedes åsyn - egentlig kongen, men hos Grundtvig altså den eller de døbte. 
Det synes således at være tydeligt, at Grundtvig fra 1830'rne gjorde omfattende brug af Septuaginta, når han skulle citere fra Gammel Testamente, og hans bibelkyndige læsere og tilhørere må have undret sig. Men for poesiens vedkommende fik det for alvor betydning, fordi Septuaginta efter Grundtvigs temperament var mere "poetisk « end 1736-Bibelen med dens knudrede og til tider næsten uforståelige version især af psalmerne. Men først og sidst realiserede han dermed den idé, han havde fåt fra Irenæus, ved at knytte sig til den Bibel, der var Ny Testamentes og den gamle kirkes.

Noter

* Foredrag ved et seminar 27. februar 1998 i anledning af professor dr. theol. Jakob Ballings afsked.

1 25. søndag efter trinitatis 1821 (Grundtvigs Prast $\phi$-Pradikener, bind 2 (Kbh. 1988), s. 385f).

2 Juledag 1824 (Grundtvigs Pradikener, bind 3 (Kbh. 1983), s. 9 og 46).

3 Se Lise Helweg: Til Glade for Graad - om V-strukturen $i$ Grundtvigs "håbssalme" (For sammenhaengens skyld (Red. Chr. Thodberg) (1977), s. 24759).

4 Grundtvigs Erindringer og Erindringer om Grundtvig (Kbh. 1948), s. 25.

5 Kort Begreb af Verdens Krønike, betragtet i Sammenhang (Kbh. 1814), s. 190.

6 Se min afhandling Om Grundtvigs poetik med sarligt henblik på den bibelske inspiration (Grundtvig-Studier 1982, s. 20-45).

7 Se Grundtvigs Irenæus-oversættelse: Om Legemets Opstandelse og Deel i Guds Rige (Theologisk Maanedsskrift, 11. bind (Kbh. 1827), s. 193f., noten. Jeg er hjulpet på vej af Hejne Simonsen: Grundtvig som exeget (N.F.S. Grundtvig. Theolog og Kirkelarer (1983), s. 20-32).

8 Jf. især Mogens Müller: Kirkens første Bibel. Hebraica sive graeca veritas? (Kbh. 1994). 
9 Sognepræst Jette Holm har henledt min opmærksomhed på denne prædiken (Grundtvig-arkivet, fasc. 31).

10 I denne forbindelse lægger man også mærke til, at Grundtvig i sin prædiken citerer vers 9-10 i Esajas 35 så udførligt, dvs. ordene om, at de genløste skal vende tilbage til Sion. Det er uden tvivl inspirationen til stroferne 10-15 i Blomstre som en Rosen-Gaard, hvor samtiden vender tilbage til kristendommen. Tilmed bliver tonen i strofe 12 personlig, når det hedder »vi«:

Medens vi, som tale end,

Troed, tvivled, traf igien

Herrens Aand i Støvet.

Med henvisning til den kursiverede 2. linie med gentagelsen af datidsformerne af verbet, mindes man om det samme fænomen i digtet Farvel til Sibbern (1811):

Da hastede jeg ud fra Akselstad,

jeg takkede, jeg higed, jeg bad

(Poetiske Skrifter I, s. 284), der refererer til Grundtvigs ejendommelige oplevelse, da han vendte hjem til faderen og den gamle kristendom og fattede mod dertil, da Herren talte ham i skoven uden for Udby 31. maj 1811. Når Grundtvig flere år senere - i 1824 - tydeligvis mindes denne dag, taler han i samme sproglige stil:

jeg troede, jeg tvivlede, jeg haabede jeg frygtede, jeg knurrede, jeg takkede,...

(Grundtvigs Praedikener, bind 2 (Kbh. 1983), s. 284), jf. min afhandling Grundvigs skovoplevelse i 1811 (Grundtvig-Studier 1986, s. 11-55).

1 Stedet er lidt udvidet og mere dramatiseret i Septuaginta.

12 1. søndag efter trinitatis 1836 (Grundtvigs Pradikener, bind 9 (Kbh. 1985), s. 239f.)).

13 Trinitatis søndag 1844 (Grundtvig-arkivet, fasc. 33). Af håndskriftet fremgår, at Grundtvig har haft store kvaler med oversættelsen af Septuaginta. Sognepræst Jette Holm har gjort mig opmærksom på dette og et andet sted (Hoseas 6,2-9 citeres efter Septuaginta på 4. søndag i advent 1843 (Grundtvig-arkivet, fasc. 32), der jo traditionelt tolkes som vidnesbyrd om opstandelsen i Gammel Testamente. Disse henvisninger til Septuaginta-versionen til bekræftelse af opstandelsen kan betragtes som en fortsættelse af Grundtvigs henvisninger i Om Legemets Opstandelse og Deel $i$ Guds Rige (se ovenfor) til skriftsteder, der kan tydes i samme retning: Ezekiel 37,1-14 (anf.skr., s. 194f.) og 265), Esajas 65,22 (s. 195), Ps. 85,13 (s.254), Esajas 26,19 (s. 265), Esajas 58,15 (s. 266f.), Esajas 6,11 (s. 
267), Daniel 2,27 (side 267f.), Daniel 12,13 (sst.), Jeremias 31,10-14) (s. 269), Esajas 65,18 og 22 (s. 270), Esajas 26,10 (s. 271) og Ps. 119,175 (s. 30).

14

15 linier:

Hvor liflig, hvor rolig,

o Gud! er din Bolig.

20

f. en salme som DS 519: Vor Herre! til dig må jeg ty (se Lise Helweg: Til Glcede for Graad - Om V-strukturen $i$ Grundtvigs "håbssalme" (For sammenhaengens skyld (1977), s. 247-59) 
24 Randi Habersaat Rode: Barneglad og engleklog. Grundtvigs selvforståelse $i$ Sang-Vark til den danske Kirke, I (Kbh. 1996), s. 110. Det hedder videre: »Således er vejen fra den ene bolig til den anden frit tilgængelig hele livet igennem. Den bliver ikke blot nemmere og hurtigere med alderen, jf. udviklingen fra at stige $(5,5)$ til at fare $(6,8)$, men kvalitativt forbundet med en stadig mere poetisk livsopfattelse«. Denne tolkning lader sig ikke uden videre forlige med min teologiske opfattelse af Grundtvigs salmer, ligesom jeg i almindelighed kun kan beklage, at forfatteren i sine teorier om Sangværkets tilblivelse og i forbindelse med »den intertekstuelle tolkning « ikke tager hensyn til f. eks. de prædikener i 1836-37, der der både tankemæssigt og i konkret ordvalg synes at danne baggrund for salmerne, jf. mine indledninger i Grundtvigs Pradikener, bind 9 og 10 (Kbh. 1986). 